"Different means of earnings management of owner-managed firms versus agent-led firms: evidence from chaebols in Korea"

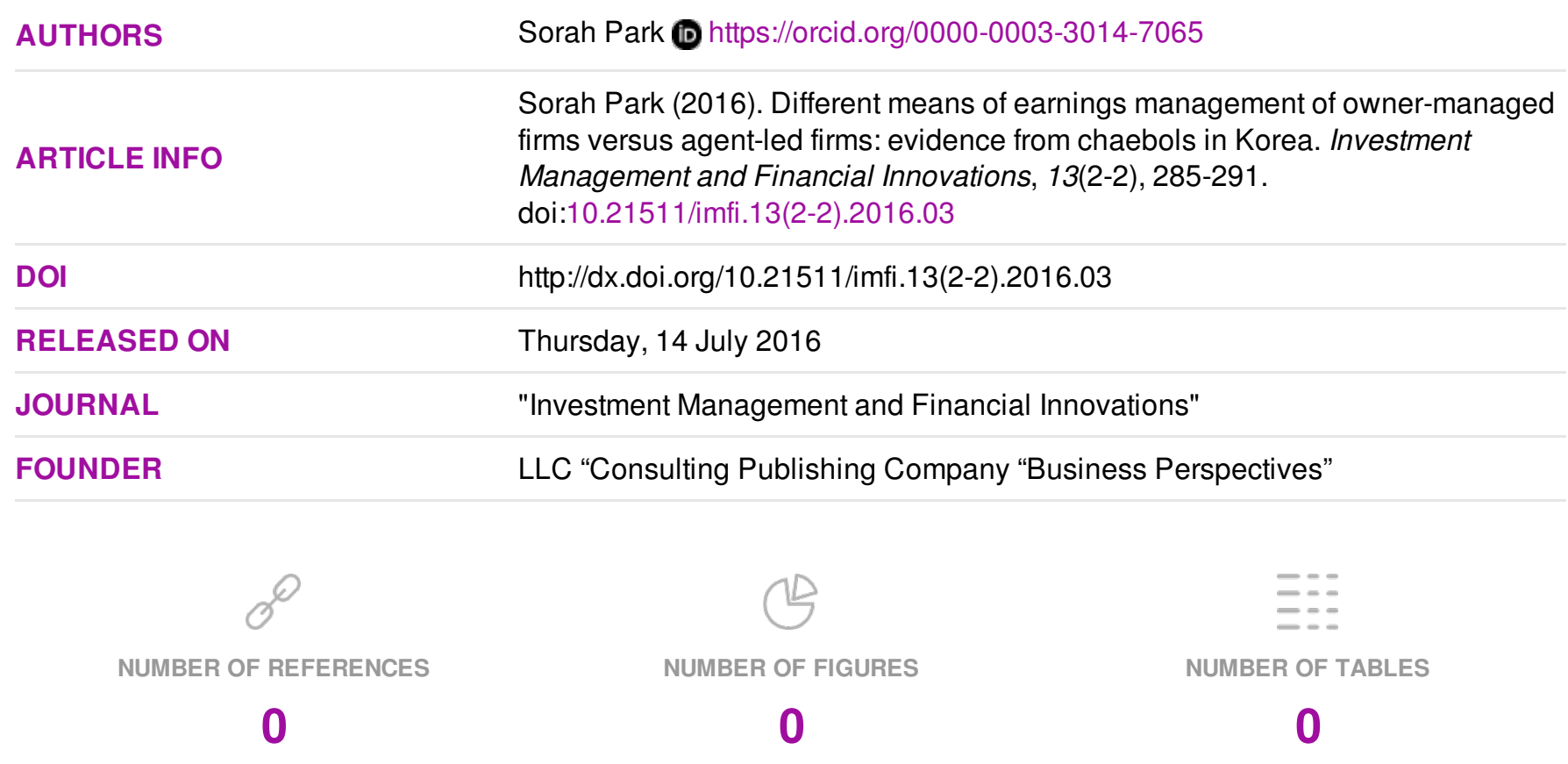

(C) The author(s) 2023. This publication is an open access article. 
Sorah Park (Korea)

\title{
Different means of earnings management of owner-managed firms versus agent-led firms: evidence from chaebols in Korea
}

\begin{abstract}
This paper examines the earnings management behavior of large, family-controlled business groups (so-called 'chaebol') in Korea from 2006 to 2010. Specifically, the author studies whether the methods of earnings management are different between chaebol firms versus non-chaebol firms. The author finds no significant difference in accrualbased earnings management by these two types of firms. However, the author shows that chaebol firms' real-based earnings management is greater than non-chaebol firms, based on their higher abnormal production costs and lower abnormal discretionary expenses, in order to manipulate accounting income upward. The results suggest that ownermanaged firms tend to choose real manipulation which negatively affects future corporate performance and consequently mislead investors about the firm value.
\end{abstract}

Keywords: discretionary accruals, real-based earnings management, chaebol, family firm. JEL Classification: M41, E32.

\section{Introduction}

This paper investigates whether owner-managed firms and agent-led firms have different means of earnings management. In Korea, large, familycontrolled business groups (so-called 'chaebol') account for a significant proportion of gross national product. Chaebol firms are usually managed by owner or founder family members, and these ownermanagers have control rights over the firm's assets and use these rights to influence the firm's decisionmaking processes. Unlike agent-led firms, managers in chaebol firms have interest aligned with owners. However, owner-managers may exert power over corporate decisions for private benefits at the expense of minority shareholders. Such unique circumstance of chaebol firms suggests that the extent of earnings management may be different for chaebol firms compared to non-chaebol firms. Furthermore, the means of earnings management (i.e., accrual-based versus real-based manipulation) may be different for chaebol firms than non-chaebol firms.

Such conjectures are empirically examined using a sample of listed companies in Korea from 2006 to 2010. I find no difference in accrual-based earnings management, which is measured by discretionary accruals, between chaebol firms and non-chaebol firms. This could be due to high political costs and auditing risk related to accrual manipulation regardless of ownership structure. However, I show that chaebol firms tend to manipulate real operating activities to a greater extent than non-chaebol firms. Specifically, they increase production activity and decrease discretionary expenses in order to manipulate earnings upward. These findings suggest that owner-managers tend to choose real manipulation which negatively

(C) Sorah Park, 2016.

Sorah Park, Ph.D., Assistant Professor of Accounting, Ewha School of Business, Ewha Womans University, Korea. affects future corporate performance and consequently mislead investors about the firm value. This also implies a greater demand for strict auditing and regulations on chaebol firms.

This paper adds to the literature on the relationship between family firm ownership and earnings management. Specifically, the author studies the effect of chaebol ownership on the different methods of earnings management in Korea. Prior research has documented that earnings management is prevalent in firms with significant Type 2 agency conflict between controlling shareholders and minority shareholders (Fan and Wong, 2002, Liu and $\mathrm{Lu}, 2007$, Bhaumik and Gregoriou, 2010). Studies based on Chinese companies (e.g., Aharony et al., 2005) find that the main motive for earnings management is tunneling and the main vehicle is transactions with related firms. However, when controlling shareholders become the true owners through highly concentrated ownership, they are likely to minimize accounting earnings in order to preserve their future growth potential (Ding et al., 2007). Ali et al. (2007) also show that family firms in China exhibit less discretionary accruals. Consistent with the latter strand, it was found no significant difference in discretionary accruals between chaebol firms and non-chaebol firms in Korea. The researcher also extends the former strand by showing that significant Type 2 agency conflict in chaebol firm results in a greater tendency of real-based earnings management.

The remainder of this paper is organized as follows. Section 1 reviews the related literature and develops hypotheses. Section 2 describes the methodology used in empirical analysis. Section 3 reports the test results and the final section concludes.

\section{Related literature and hypotheses}

This paper is closely related to two streams of literature. First, this paper adds to the earnings 
management literature. Schipper (1989) defines earnings management as "the purposeful intervention in the external financial reporting process, with the intent of obtaining some private gain (as opposed to merely facilitating the neutral operation of the process)." One survey conducted in Korea documented that more than $80 \%$ of listed companies on KOSPI and KOSDAQ are engaging in such disclosure management actions. There are several strands of research on the incentives of earnings management. First, executive compensation hypothesis (Holmstrom, 1982) posits that managers are inclined to manage earnings in order to maximize their compensation, since executive pay depends on firm performance relative to competitors. Second, according to debt covenant hypothesis, firms which are close to violating debt covenants are more likely to engage in upward earnings management to avoid high contracting costs (such as early redemption, higher interest rate) (Defond and Jiambalvo, 1994). Third, companies with higher political costs may have incentives for downward earnings management or income smoothing in order to defer current period earnings to the future periods. This paper attempts to examine whether owner-managed and agent-led firms have different incentives for such financial reporting behavior.

Next, the discussion on owner-managed and agent-led firms stems from the agency theory (Jensen and Meckling, 1976). The agents may have different interests to those of owners due to the separation of ownership and management, thereby acting to maximize their private benefits at the expense of owners. However, for owner-managed firms, such agency problem is mitigated, since the owner is in control. Instead, there is another form of agency conflicts between controlling shareholders and minority shareholders. Owner family (controlling shareholders) can exert significant power on important business decisions to maximize their own wealth even if it hurts the minority shareholders (La Porta et al. 1999). This type of agency cost becomes greater when there is no control mechanism to protect minority shareholders against controlling shareholders. In Korea, large conglomerates, so-called 'chaebol' firms, are considered owner-managed ones in which founder family members influence major business decisions and control the significant number of shares.

There are two opposing hypotheses that can explain the effect of such ownership structure on their financial reporting behavior. According to the view on the convergence of interest, owner-manager would want to maximize the firm value, since there is no agency conflict between owners and managers. Thus, there is less incentive for earnings management in owner-managed than in agent-led firms. On the other hand, management entrenchment view argues that owner-manager is inclined to build the empire and maximize their private benefits by abusing corporate resources. Based on such view, the agency conflict between controlling and minority shareholders is significant in chaebol firms. Therefore, the owner-managed firms are more likely to manipulate earnings at the expense of minority shareholders. These opposing predictions lead to the first hypothesis as follows:

H1: Earnings management will be greater (less) in chaebol firms than in non-chaebol firms.

In addition, the means to manipulate financial statements may differ by ownership structures. Prior research has mainly documented two means of earnings management. First, companies may manipulate accruals to report favorable accounting income. Such discretionary component of accruals is measured using various models including the modified Jones model (Dechow et al., 1995). Second, companies also manage earnings by changing real operating activities (Roychowdhury, 2006). Such real-based manipulation is measured by abnormal operating cash flows, abnormal discretionary expenses and abnormal production costs. The choice of earnings management methods depends on the firm-specific characteristics or circumstances. Zang (2007) shows that managers use accrual manipulation and real manipulation as substitutes in managing earnings. Specifically, after lawsuit filings, managers are documented to switch from accrual management to real manipulation.

The means of earnings management may be affected by their potential costs, which is different for ownermanaged and agent-led companies. Managers in agentled companies have a risk-averse tendency, since their job security is harmed by risky investments and poor (short-term) performance. By contrast, ownermanagers have a longer horizon than owner-managers do (Fama and Jensen, 1983). This implies that ownermanaged and agent-led companies could face very different trade-offs between accrual-based and realbased manipulation. Therefore, the second hypothesis is stated as follows:

H2: Chaebol and non-chaebol firms will have different means of earnings management.

\section{Research methods}

2.1. Data and sample. Our sample consists of listed companies on KOSPI and KOSDAQ from 2006 to 2010. The sample period ends in 2010, because the new accounting standard (Korean International Financial Reporting Standard) was adopted in 2011. The author collects the financial variables used in data analysis from TS2000 database. 
He imposes the following data requirements on the initial sample. First, firms in financial and insurance industries are deleted since their financial statements are not comparable to the other industries. Second, firms with non-December fiscal year-end are excluded. Third, firms with impaired capital, negative total assets, or negative book equity are deleted. After I remove firm-years with missing data for tests, the final sample contains 2,184 firm-year observations (478 distinct firms). For a regression purpose, all variables are winsorized at top $99 \%$ and bottom $1 \%$.

\subsection{Variables.}

(1) Chaebol: owner-managed versus agent-led firms

In general, firms in which the founder or his/her family member is an executive are classified as owner-managed firms and the others as agent-led firms (e.g., Anderson and Reeb, 2003). In Korea, large conglomerate groups, so-called chaebols, are composed of owner-managed companies in which controlling shareholder or founder family member is an executive or a chairman on the board (Jeong and Bae, 2007). These companies have significant related party transactions among subsidiaries, and the Fair Trade Committee restricts such mutual contributions. The committee announces the list of companies which are restricted on mutual contribution based on their total assets in April every year. Hence, the author classifies the companies on this list as owner-managed ones and the others as agent-led ones.

\section{(2) Accrual-based earnings management}

Accounting literature has widely used the discretionary portion of accruals in order to detect earnings management. Following Dechow et al. (1995) and Kothari et al. (2005), the author calculates discretionary accruals based on the modified Jones model, which is adjusted for ROA. Total accruals are computed by subtracting operating cash flows from net income. Then, the following regression equation is used to estimate the normal (non-discretionary) component of accruals:

$$
T A C_{i t}=\beta_{0}+\beta_{1} \Delta \operatorname{Rev}_{i t}+\beta_{2} P P E_{i t}+\beta_{3} R O A_{i, t-1}+\varepsilon_{i t},
$$

where, TAC is total accruals for firm $i$ during year $t$, $R e v$ is the revenue for firm $i$ in year $t, P P E$ denotes property, plant and equipment for firm $i$ at the end of year $t$, and ROA is return on total assets for firm $i$ in year $t-1$. All variables are scaled by the total assets at the beginning of year $t$. The derived nondiscretionary portion of accruals by using the coefficients estimated from regression equation (1), as shown in equation (2).

$$
N D A_{i t}=\hat{\beta}_{0}+\hat{\beta}_{1}\left(\Delta \operatorname{Rev}_{i t}-\Delta \operatorname{Rec} i t\right)+\hat{\beta}_{2} P P E_{i t}+\hat{\beta}_{2} R O A_{i, t-1},
$$

where, Rec is net receivables for firm $i$ at the end of year $t$. Finally, the discretionary accruals are calculated as the difference between total accruals and non-discretionary accruals, as in equation (3):

$D A_{i, t}=T A C_{i, t}-N D A_{i, t}$

$D A 1$ is the outcome when total accruals are computed by subtracting operating cash flows from net income and $D A 2$ is the outcome when total accruals are computed by subtracting operating cash flows from operating income. Also, in order to capture both upward and downward accrual-based earnings management, The author uses the absolute value of discretionary accruals, i.e., $A b s(D A 1)$ and $A b s(D A 2)$.

\section{(3) Real-based earnings management}

Real-based earnings management is measured following the approach taken by Roychowdhury (2006). Roychowdhury (2006) estimates the normal level of operating cash flows, production costs, and discretionary expenses based on the cross-sectional regression models (at industry year), as shown in equations (4) (6):

$$
\begin{aligned}
& \left(\frac{C F O_{t}}{A_{t-1}}\right)=\alpha_{0}+\alpha_{1}\left(\frac{1}{A_{t-1}}\right)+\beta_{1}\left(\frac{S_{t}}{A_{t-1}}\right)+\beta_{2}\left(\frac{\Delta S_{t}}{A_{t-1}}\right)+\varepsilon_{t}, \\
& \left(\frac{P R O D_{t}}{A_{t-1}}\right)=\alpha_{0}+\alpha_{1}\left(\frac{1}{A_{t-1}}\right)+\beta_{1}\left(\frac{S_{t}}{A_{t-1}}\right)+\beta_{2}\left(\frac{\Delta S_{t}}{A_{t-1}}\right)+\beta_{3}\left(\frac{\Delta S_{t-1}}{A_{t-1}}\right)+\varepsilon_{t}, \\
& \left(\frac{D I S X_{t}}{A_{t-1}}\right)=\alpha_{0}+\alpha_{1}\left(\frac{1}{A_{t-1}}\right)+\beta_{1}\left(\frac{S_{t-1}}{A_{t-1}}\right)+\varepsilon_{t},
\end{aligned}
$$

where, $C F O$ is operating cash flows during year $t, S$ is the sales revenue for year $t, A$ is the total assets at the beginning of year $t, P R O D$ is the production cost for year $t(=C O G S+\triangle I N V), D I S X$ is discretionary expenses during year $t(=$ Selling and General expense, Taxes, Depreciation, Rent expenses, Insurance expense).

Normal level operating cash flows, production costs and discretionary expenses are calculated using the coefficient estimates $\left(\hat{\alpha}_{0}, \hat{\alpha}_{1}, \hat{\beta}_{1}, \hat{\beta}_{2}, \hat{\beta}_{3}\right)$ from equations (4) (6). Then, I subtract these normal values from their raw values to obtain the abnormal CFOs, abnormal production costs, and abnormal discretionary expenses. For the simplicity of interpretation, real-based earnings management measures are defined as follows: $A C F O=$ abnormal $C F O^{*}(-1) ; A P R O D=$ abnormal PROD; ADISX $=$ abnormal DISC EXP*(-1).

Also, companies may utilize more than one device to manipulate real activities. Thus, following Cohen et al. (2008) and Cohen and Zarowin (2010), a comprehensive measure of real-based management is defined as follows:

$R E M=A C F O+A P R O D+A D I S X$. 


\section{(4) Control variables}

A standard set of controls for regression analyses is used. First, firm size is measured as natural logarithm of a firm's total assets. Large firms have greater political costs and consequently they have greater incentives to smooth earnings than small firms (e.g., Moses, 1987). By contrast, there is more available information and less information asymmetry for large firms. This implies that they have less incentive for income smoothing or earnings management (e.g., Albrecht and Richardson, 1990; Choi and Lee, 2002).

Also, Debt is measured as total liabilities divided by total assets. Highly levered firms are likely to manage accounting income in order to avoid debt covenant violation (Defond and Jiambalvo, 1994). Next, market-to-book (MTB) ratio is included as a proxy for a firm's growth opportunities. Firms with greater growth opportunities face higher operating uncertainty, thereby having greater incentives to report highquality financial statements to reduce the information asymmetry between the firm and external capital providers. In addition, $R O A$ is added to control the effect of firm profitability on accounting quality.

Moreover, the author adds three more control variables which proxy for audit quality, information environment, and corporate governance. First, a dummy for big 4 auditors (Big4) is included to control for audit quality, since Big4 auditors are documented to be better at constraining a client's earnings management compared to non-Big4 auditors (e.g., Krishnan, 2003). Second, analyst following is included as a proxy for a firm's information environment, as more analysts who cover the firm may impose higher pressure to meet or beat the earnings targets and consequently these firms are more inclined to manage earnings. A dummy variable (i.e., Following) that is set to 1 for firms with at least one analyst following the firm, and 0 elsewhere is used. Third, corporate governance is included, because better governed companies are less likely to engage in accrual-based or real-based earnings management. Hence, the author uses the corporate governance score (i.e., Gscore) which is based on the shareholder protection, board of directors, disclosure, and audit system (provided by Korea Corporate Governance Service).

\section{Test results}

A. Descriptive statistics. Table 1 provides the summary statistics of test variables. The means and medians of accrual-based earnings management measures (i.e., absolute value of discretionary accruals) are not significantly different between chaebol firms and non-chaebol firms. However, realbased earnings management measures seem to differ for chaebol firms. $A P R O D$ and ADISC (ACFO and $R E M$ ) are greater (smaller) for chaebol firms than non-chaebol firms, on average. This implies that chaebol firms tend to manipulate their production activity to decrease $C O G S$ and decrease discretionary expenditures to manipulate earnings upward.

Chaebol and non-chaebol firms seem to have different firm characteristics and information environment as well. Specifically, chaebol firms have larger size, higher profitability, better governance, and less debt, on average. Also, chaebol firms are more likely to be covered by analysts and audited by Big4 auditors.

Table 1. Summary statistics of key variables

\begin{tabular}{|c|c|c|c|c|c|c|c|}
\hline Chaebol & $N$ & Variable & Mean & Std & P25 & Med & P75 \\
\hline \multirow{13}{*}{0} & \multirow{13}{*}{1612} & $A b s(D A 1)$ & 0.0541 & 0.0509 & 0.0174 & 0.0397 & 0.0737 \\
\hline & & $A b s(D A 2)$ & 0.0613 & 0.0566 & 0.0201 & 0.0450 & 0.0832 \\
\hline & & ACFO & 0.0031 & 0.0746 & -0.0409 & 0.0028 & 0.0473 \\
\hline & & $A P R O D$ & 0.0042 & 0.0992 & -0.0497 & 0.0063 & 0.0614 \\
\hline & & ADISC & 0.0007 & 0.0816 & -0.0303 & 0.0121 & 0.0440 \\
\hline & & REM & 0.0080 & 0.1994 & -0.0991 & 0.0213 & 0.1263 \\
\hline & & Size & 8.5843 & 1.7376 & 7.3045 & 8.5416 & 9.7181 \\
\hline & & Debt & 0.1558 & 0.1393 & 0.0308 & 0.1303 & 0.2369 \\
\hline & & MTB & 0.1924 & 0.4304 & 0.0148 & 0.0463 & 0.1533 \\
\hline & & $R O A$ & 0.0321 & 0.0831 & 0.0069 & 0.0359 & 0.0757 \\
\hline & & Following & 0.3139 & 0.4642 & 0 & 0 & 1 \\
\hline & & Big4 & 0.6030 & 0.4894 & 0 & 1 & 1 \\
\hline & & Gscore & 0.3474 & 0.0638 & 0.3067 & 0.3400 & 0.3800 \\
\hline \multirow[t]{5}{*}{1} & 575 & $A b s(D A 1)$ & 0.0519 & 0.0489 & 0.0168 & 0.0366 & 0.0700 \\
\hline & & $A b s(D A 2)$ & 0.0569 & 0.0532 & 0.0202 & 0.0400 & 0.0767 \\
\hline & & ACFO & -0.0047 & 0.0730 & -0.0484 & -0.0060 & 0.0423 \\
\hline & & $A P R O D$ & 0.0063 & 0.0939 & -0.0459 & 0.0125 & 0.0607 \\
\hline & & ADISC & 0.0054 & 0.0704 & -0.0214 & 0.0099 & 0.0435 \\
\hline
\end{tabular}


Table 1 (cont.). Summary statistics of key variables

\begin{tabular}{|l|l|l|c|c|c|c|c|}
\hline Chaebol & $N$ & \multicolumn{1}{|c|}{ Variable } & Mean & Std & P25 & Med & P75 \\
\hline \multirow{5}{*}{} & & REM & 0.0071 & 0.1838 & -0.0970 & 0.0236 & 0.1124 \\
\cline { 3 - 8 } & Size & 10.8374 & 2.4308 & 9.0734 & 10.9891 & 12.7959 \\
\cline { 3 - 8 } & Debt & 0.1201 & 0.1119 & 0.0252 & 0.0960 & 0.1799 \\
\cline { 3 - 8 } & MTB & 0.2082 & 0.3094 & 0.0332 & 0.1095 & 0.2411 \\
\cline { 3 - 8 } & ROA & 0.0434 & 0.0744 & 0.0124 & 0.0461 & 0.0831 \\
\cline { 3 - 8 } & Following & 0.6800 & 0.4669 & 0 & 1 & 1 \\
\cline { 3 - 8 } & Big4 & 0.8991 & 0.3014 & 1 & 1 & 1 \\
\cline { 3 - 8 } & Gscore & 0.4288 & 0.1019 & 0.3533 & 0.4100 & 0.5033 \\
\hline
\end{tabular}

B. Main test results. First set of regression analysis examines whether accrual-based earnings management is greater for owner-managed firms than for agent-led firms. In Table 2, the first and second columns show the results when the dependent variable is the absolute value of discretionary accruals based on net income and operating income, respectively, namely $A b s(D A 1)$ and $A b s(D A 2)$.
In both columns, the regression coefficient on chaebol dummy variable is not statistically significant. This suggests that the accrual-based earnings management of chaebol firms is not significantly different than other firms. Since chaebol firms are subject to high political costs and risks in case of getting detected by the authorities, they do not particularly engage in accrual manipulation to a greater extent compared to non-chaebol firms.

Table 2. The relation between accrual-based earnings management and chaebol firms

\begin{tabular}{|c|c|c|c|c|}
\hline & \multicolumn{2}{|c|}{ Panel A: $A b s(D A 1)$} & \multicolumn{2}{|c|}{ Panel B: $A b s(D A 2)$} \\
\hline & Parameter & $t$-value & Parameter & $t$-value \\
\hline Intercept & 0.0126 & 0.35 & 0.0360 & 0.87 \\
\hline Chaebol & -0.0018 & -0.62 & -0.0012 & -0.36 \\
\hline Size & 0.0009 & 1.25 & 0.0011 & 1.44 \\
\hline Debt & 0.0634 & $7.18^{\star \star \star}$ & 0.0420 & $4.16^{\star * \star}$ \\
\hline MTB & 0.0032 & $3.07^{\star \star *}$ & 0.0053 & $4.49^{* \star *}$ \\
\hline$R O A$ & -0.0106 & -1.32 & -0.0288 & $-3.14^{\star \star \star}$ \\
\hline Following & 0.0042 & 1.49 & -0.0012 & -0.37 \\
\hline Big4 & -0.0075 & $-2.93^{\star * \star}$ & -0.0076 & $-2.61^{\star \star *}$ \\
\hline Gscore & -0.0505 & $-3.08^{\star \star \star}$ & -0.0575 & $-3.07^{\star * *}$ \\
\hline No obs & \multicolumn{2}{|c|}{2184} & \multicolumn{2}{|c|}{2184} \\
\hline Adj. $R 2$ & \multicolumn{2}{|c|}{0.0914} & \multicolumn{2}{|c|}{0.0837} \\
\hline Fixed effects & \multicolumn{2}{|c|}{ Year, industry } & \multicolumn{2}{|c|}{ Year, industry } \\
\hline
\end{tabular}

The second set of tests investigates whether realbased earnings management is greater for ownermanaged firms than for agent-led firms. Table 3 reports the test results when the dependent variable is abnormal operating cash flows, abnormal production costs, and abnormal discretionary expenses in Panel A, B, and $\mathrm{C}$, respectively. In all panels, the regression coefficient on Chaebol dummy variable is positive and statistically significant $(0.0076, t$-value $=1.85$ for $A C F O ; 0.0231, t$-value $=$
3.79 for APROD; $0.0205, t$-value $=4.12$ for $A D I S C$ ). This implies that the real-based earnings management of chaebol firms is significantly greater than other firms. More specifically, chaebol firms tend to increase productions and decrease discretionary expenses in order to manipulate accounting earnings upward. They also manipulate operating cash flows by increasing sales temporarily, but to a lesser extent.

Table 3. The relation between real-based earnings management measures and chaebol firms

\begin{tabular}{|c|c|c|c|c|c|c|}
\hline & \multicolumn{2}{|c|}{ Panel A: ACFO } & \multicolumn{2}{|c|}{ Panel B: APROD } & \multicolumn{2}{|c|}{ Panel C: ADISC } \\
\hline & Parameter & $t$-value & Parameter & $t$-value & Parameter & $t$-value \\
\hline Intercept & 0.0002 & 0 & -0.1442 & $-1.93^{* \star}$ & 0.0787 & 1.29 \\
\hline Chaebol & 0.0076 & $1.85^{\star}$ & 0.0231 & $3.79^{\star \star \star}$ & 0.0205 & $4.120^{\star \star \star}$ \\
\hline Size & -0.0001 & -0.06 & -0.0010 & -0.67 & -0.0010 & -0.77 \\
\hline Debt & 0.1739 & $14.13^{\text {***}}$ & 0.1040 & $5.66^{\star \star \star}$ & 0.0309 & $2.06^{* *}$ \\
\hline MTB & 0.0007 & 0.48 & -0.0018 & -0.81 & -0.0112 & $-6.42^{\star \star \star}$ \\
\hline$R O A$ & -0.1009 & $-9.01^{* * *}$ & -0.0926 & $-5.54^{\star * *}$ & 0.0263 & $1.94^{* *}$ \\
\hline Following & -0.0142 & $-3.58^{\star * *}$ & -0.0099 & $-1.68^{\star}$ & -0.0076 & -1.58 \\
\hline
\end{tabular}


Table 3 (cont.). The relation between real-based earnings management measures and chaebol firms

\begin{tabular}{|c|c|c|c|c|c|c|}
\hline & \multicolumn{2}{|c|}{ Panel A: ACFO } & \multicolumn{2}{|c|}{ Panel B: APROD } & \multicolumn{2}{|c|}{ Panel C: ADISC } \\
\hline & Parameter & $t$-value & Parameter & $t$-value & Parameter & $t$-value \\
\hline Big4 & 0.0018 & 0.52 & 0.0012 & 0.23 & -0.0022 & -0.51 \\
\hline Gscore & -0.0518 & $-2.27^{\star \star}$ & -0.2005 & $-5.87^{\star \star \star}$ & -0.1671 & $-6.02^{\star * \star}$ \\
\hline No obs & \multicolumn{2}{|c|}{2184} & \multicolumn{2}{|c|}{2184} & \multicolumn{2}{|c|}{2184} \\
\hline Adj. $R 2$ & \multicolumn{2}{|c|}{0.1678} & \multicolumn{2}{|c|}{0.0730} & \multicolumn{2}{|c|}{0.0655} \\
\hline Fixed effects & \multicolumn{2}{|c|}{ Year, industry } & \multicolumn{2}{|c|}{ Year, industry } & \multicolumn{2}{|c|}{ Year, industry } \\
\hline
\end{tabular}

I also examine the relationship between a comprehensive measure of real-based earnings management and chaebol firms. Table 4 reports the test results when the dependent variable is REM, which is the sum of abnormal operating cash flows, abnormal production costs, and abnormal discretionary expenses. Consistent with individual test results, I find that the regression coefficient on Chaebol dummy variable is positive and statistically significant at $1 \%$ level $(0.0512, t$-value $=4.37)$.

Taken together, the evidence suggests that chaebol firms are more likely to manipulate real operating activities, not accruals, so as to report more favorable earnings. These findings imply that owner-managers have a longer horizon than agents; hence, they could use the channels with long-term impacts on firm value in order to manipulate shortterm earnings.

Table 4. The relation between comprehensive real-based earnings management measure and chaebol firms

\begin{tabular}{|l|c|c|}
\hline & \multicolumn{2}{|c|}{ Dependent variable: REM } \\
\hline & Parameter & $t$-value \\
\hline Intercept & -0.0654 & -0.45 \\
\hline
\end{tabular}

\begin{tabular}{|l|c|c|}
\hline Chaebol & 0.0512 & $4.37^{* \star *}$ \\
\hline Size & -0.0019 & -0.7 \\
\hline Debt & 0.3088 & $8.76^{* \star *}$ \\
\hline MTB & -0.0123 & $-2.98^{\star \star \star}$ \\
\hline ROA & -0.1672 & $-5.21^{\star \star *}$ \\
\hline Following & -0.0317 & $-2.79^{\star \star *}$ \\
\hline Big4 & 0.0009 & 0.08 \\
\hline Gscore & -0.4194 & $-6.4^{\star \star *}$ \\
\hline No obs & \multicolumn{2}{|c|}{0.1038} \\
\hline Adj. R2 & \multicolumn{2}{|c|}{ Year, Industry } \\
\hline Fixed effects & \multicolumn{2}{|c|}{} \\
\hline
\end{tabular}

\section{Conclusions}

This paper examines whether the methods of earnings management are related to the family firm ownership, which is proxied by a chaebol firm dummy, in Korea. The evidence shows that chaebol firms use real-based earnings management to a greater extent, but not the discretionary accruals, in order to report favorable accounting earnings. This suggests that owner-managers tend to sacrifice longterm firm value through manipulating productions and discretionary activities. Hence, the findings of this paper suggest that external auditors and regulatory authorities need to enhance the monitoring over chaebol firms.

\section{References}

1. Aharony, J., Wang, J. \& Yuan, H. (2010). Tunneling as an incentive for earnings management during the IPO process in China, Journal of Accounting and Public Policy, 29(1), pp. 1-26.

2. Albrecht, W.D. \& Richardson, F.M. (1990). Income smoothing by economy sector, Journal of Business Finance \& Accounting, 17(5), pp. 713-730.

3. Ali, A., Chen, T.Y. \& Radhakrishnan, S. (2007). Corporate disclosures by family firms, Journal of Accounting and Economics, 44(1), pp. 238-286.

4. Anderson, R.C. \& Reeb, D.M. (2003). Founding-family ownership and firm performance: evidence from the S\&P 500, The Journal of Finance, 58(3), pp. 1301-1328.

5. Bhaumik, S.K. \& Gregoriou, A. (2010). Family ownership, tunneling and earnings management: a review of the literature, Journal of Economic Surveys, 24(4), pp. 705-730.

6. Choi, W.S. \& Lee, W.B. (2005). Is family ownership a determinant of firm performance? The Korean Journal of Finance, 18(1), pp. 121-155. [Printed in Korean].

7. Cohen, D.A., Dey, A. \& Lys, T.Z. (2008). Real and accrual-based earnings management in the pre-and postSarbanes-Oxley periods, The Accounting Review, 83(3), pp. 757-787.

8. Cohen, D.A. \& Zarowin, P. (2010). Accrual-based and real earnings management activities around seasoned equity offerings, Journal of Accounting and Economics, 50(1), pp. 2-19.

9. Dechow, P.M., Sloan, R.G. \& Sweeney, A.P. (1995). Detecting earnings management, The Accounting Review, pp. 193-225.

10. DeFond, M.L. \& Jiambalvo, J. (1994). Debt covenant violation and manipulation of accruals, Journal of Accounting and Economics, 17(1), pp. 145-176.

11. Ding, Y., Zhang, H. \& Zhang, J. (2007). Private vs state ownership and earnings management: evidence from Chinese listed companies, Corporate Governance: An International Review, 15(2), pp. 223-238. 
12. Fama, E.F. \& Jensen, M.C. (1983). Separation of ownership and control, The Journal of Law \& Economics, 26(2), pp. 301-325.

13. Fan, J.P. \& Wong, T.J. (2002).Corporate ownership structure and the informativeness of accounting earnings in East Asia, Journal of Accounting and Economics, 33(3), pp. 401-425.

14. Holmstrom, B. (1982). Moral hazard in teams, The Bell Journal of Economics, pp. 324-340.

15. Jensen, M.C. \& Meckling, W.H. (1976). Theory of the firm: Managerial behavior, agency costs and ownership structure, Journal of Financial Economics, 3(4), pp. 305-360.

16. Jeong, J.W. \& Bae, G.S. (2007). Long-run stock price performance of the firms that grant stock options and the separation of ownership and management, Korean Financial Management Research, 24(1), pp. 149-182. [Printed in Korean].

17. Kothari, S.P., Leone, A.J. \& Wasley, C.E. (2005). Performance matched discretionary accrual measures, Journal of Accounting and Economics, 39(1), pp. 163-197.

18. Krishnan, G.V. (2003). Audit quality and the pricing of discretionary accruals, Auditing: A Journal of Practice \& Theory, 22(1), pp. 109-126.

19. La Porta, R., Lopez-de-Silanes, F., Shleifer, A. \& Vishny, R. (1999). The quality of government, Journal of Law, Economics, and Organization, 15(1), pp. 222-279.

20. Liu, Q. \& Lu, Z.J. (2007). Corporate governance and earnings management in the Chinese listed companies: a tunneling perspective, Journal of Corporate Finance, 13(5), 881-906.

21. Moses, O.D. (1987). Income smoothing and incentives: empirical tests using accounting changes, The Accounting Review, pp. 358-377.

22. Roychowdhury, S. (2006). Earnings management through real activities manipulation, Journal of Accounting and Economics, 42(3), pp. 335-370.

23. Schipper, K. (1989). Commentary on earnings management, Accounting Horizons, 3(4), pp. 91-102.

24. Zang, A.Y. (2011). Evidence on the trade-off between real activities manipulation and accrual-based earnings management, The Accounting Review, 87(2), pp. 675-703. 